\title{
Ultra-Performance Liquid Chromatography-Triple Quadruple Mass Spectrometry (UPLC-TQ/MS) for Evaluation of Biogenic Amines in Wine
}

\author{
Krste Tašev $^{1,2}$ • Violeta Ivanova-Petropulos ${ }^{3}$ - Marina Stefova ${ }^{2}$
}

Received: 5 January 2017 / Accepted: 10 May 2017 / Published online: 27 June 2017

(C) Springer Science+Business Media New York 2017

\begin{abstract}
In this study, a fast, simple, and sensitive analytical method for direct determination of biogenic amines tryptamine, putrescine, histamine, phenylethylamine, tyramine, cadaverine, spermine, and spermidine in wine has been developed and validated. Detection of analytes was performed with ultra-performance liquid chromatography (UPLC) coupled to triple quadruple mass spectrometer (TQ/MS). The calibration curves of all amines were linear with correlation coefficients $\left(R^{2}\right)$ ranging from 0.9906 for putrescine to 0.9998 for histamine and 2-phenyethylamine. The accuracy of the method was checked with a standard addition method, showing good accuracy, repeatability, and reproducibility $(R S D<10 \%)$. The limit of detection (LOD) and limit of quantification (LOQ) ranged from 0.50 to $30 \mu \mathrm{g} / \mathrm{L}$ and 1.50 to $90 \mu \mathrm{g} / \mathrm{L}$, respectively, for all amines. The validated method was applied to detect and quantify biogenic amines in Macedonian red and white wines. Higher concentration of amines was observed in red wines $(5797 \mu \mathrm{g} / \mathrm{L}$, on average) compared to the white wines (1485 $\mu \mathrm{g} / \mathrm{L}$, on average).
\end{abstract}

Keywords Wine $\cdot$ Biogenic amines $\cdot$ Validation . UPLC-TQ/MS

Violeta Ivanova-Petropulos violeta.ivanova@ugd.edu.mk

1 State Phytosanitary Laboratory, bul. Alexander the Great bb, 1000 Skopje, Republic of Macedonia

2 Institute of Chemistry, Faculty of Natural Sciences and Mathematics, Ss Cyril and Methodius University, Arhimedova 5, Skopje, Republic of Macedonia

3 Faculty of Agriculture, "Goce Delčev" University, Krste Misirkov bb, Štip, Republic of Macedonia

\section{Introduction}

Biogenic amines (BAs) are naturally occurring low molecular weight organic bases. In wine, they are formed during the must fermentation by yeasts and lactic bacteria (Manetta et al. 2016). The amount of biogenic amines in wine is related with climatic and geological factors of the wine regions as well as to grape variety and vinification practices (Guo et al. 2015; Anli and Bayram 2009; Martuscelli et al. 2013). It has been reported that biogenic amines are formed by decarboxylation of the corresponding amino acids by microorganisms through substrate-specific decarboxylase enzymes (Preti et al. 2016) and by amination and/or transamination of aldehydes and ketones (Jastrzębska et al. 2016; Goñi and Azpilicueta 2001). Many technological and environmental factors influence the occurrence of biogenic amines in wines, such as skin maceration, contact with lees, treatments with yeast mannoproteins or proteolytic enzymes, and addition of clarification substances such as bentonite or polyvinylpolypirrolidone (PVPP) (Alcaide-Hidalgo et al. 2007; Hernández-Orte et al. 2008; Marques et al. 2008; Pérez-Serradilla and Luque de Castro 2008; Martín-Álvarez et al. 2006; García-Marino et al. 2010; Preti and Vinci 2016).

Histamine (HIST), tyramine (TYR), and cadaverine (CAD) are the most representative biogenic amines of the wine; other amines such as putrescine (PUT), 2-phenylethylamine (PEA), spermine (SPM), and spermidine (SPD) are also present in the grape must and wine (Rios and Valcarel 1998; Lonvaud-Funel 2001; Loukou and Zotou 2003; Moreno-Arribas and Polo 2005; Landete et al. 2007; Onal 2007). At high concentrations, they may be responsible for undesirable toxicological effects, such as headache, respiratory distress, heart palpitation, hypotension, hypertension, nausea, and dizziness (EFSA 2011). Tyramine alone, or with 2-phenylethylamine, causes headache due to their vasoconstrictive properties, while 
histamine, except headaches, causes low blood pressure, heart palpitations, edema, vomiting, and diarrhea (Littlewood et al. 1988; Smit et al. 2008). These effects depend on the individual sensitivity and simultaneous presence of co-factors such as ethanol, drugs, or other biogenic amines (Lonvaud-Funel 2001; Marcobal et al. 2006).

Monitoring of biogenic amine levels in wines can be an important marketing advantage. Actually, for the wine industry, there are no regulation limits of BAs established, only a recommended upper limit for histamine in red and white wine, $2 \mathrm{mg} / \mathrm{L}$ (Maintz and Novak 2007; Spano et al. 2010). The only country that has established an official maximum limit for the presence of histamine in wines $(10 \mathrm{mg} / \mathrm{L})$ was Switzerland, but this country has removed it in imported wines (Martuscelli et al. 2013). Generally, the toxic dose in alcoholic beverages is considered to be between 8 and $20 \mathrm{mg} / \mathrm{L}$ for histamine and 25 and $40 \mathrm{mg} / \mathrm{L}$ for tyramine, whereas lower values than $3 \mathrm{mg} / \mathrm{L}$ of phenylethylamine can cause negative physiological effects (Soufleros et al. 1998).

Determination of biogenic amines is a complex and challenging analysis because of their low concentrations in wine, wine matrix complexity, their structure, strong polarity, and presence of potentially interfering structurally similar substances. The most frequently reported technique for BA analysis in wine, as well as in other food samples, is liquid chromatography (LC) coupled to UV-Vis or fluorimetric detection (Sentellas et al. 2016), with pre- or post-column chemical derivatization using different derivatization reagents: dansyl chloride (DnsC1) (Tašev et al. 2016; Manetta et al. 2016), ophthalaldeyde (OPA) (Arrieta and Prats-Moya 2012; Kelly et al. 2010; Vidal-Carou et al. 2003), dabsyl chloride (Dabs$\mathrm{Cl}$ ) (Romero et al. 2000), benzoyl chloride (Bnz-Cl) (Ozdestan and Üren 2009), fluorenylmethylchloroformate (FMOC) (Bauza et al. 1995), 1,2-naphthoquinone-4-sulphonate (NQS) (Hlabangana et al. 2006), and 6-aminoquinolyl-Nhydroxysuccinimidyl carbamate (AQC) (Hernández-Orte et al. 2006). In addition, biogenic amines can be determined by capillary electrophoresis (CE) (Herrero et al. 2014), gas chromatography (GC) (Fernandes and Ferreira 2000), and enzymatic methods (Lange and Wittmann 2002). Moreover, determination of biogenic amines in wine can be performed either with conventional HPLC or ultra-high-performance liquid chromatography (UHPLC) coupled with MS detector (Sagratini et al. 2012; Daniel et al. 2015), which is the most powerful analytical tool for organic compound analysis allowing direct injection of the wine sample without derivatization processes prior to analysis. In fact, application of MS detector has advantages due to the ability to conform the presence of biogenic amines in very difficult matrixes, as wine is. Recently, liquid chromatography coupled with tandem mass spectrometry (LC-MS/MS) and ultra-high-performance liquid chromatography coupled to a quadrupole time of flight mass spectrometry (UPLC/Q-TOF-MS) techniques have been introduced as new method approaches for analysis of biogenic amines in wines (García-Villar et al. 2009).

Limited data are available for wines from south-east Europe and the Balkans, and to the best of our knowledge, only a preliminary study on the biogenic amine composition of Macedonian wines has been performed with pre-column chemical derivatization using dansyl chloride followed by HPLC-DAD determination (Tašev et al. 2016). In order to extend that study and provide more detailed information about BAs in red and white wines, faster and more accurate method without derivatization was developed, optimized, and validated using ultra-performance liquid chromatography coupled to a triple quadrupole MS detector (UPLC-TQ/MS). The method was optimized at two product ions $(\mathrm{m} / \mathrm{z})$ for identification and quantification of the amines that give higher confidence of the results especially in a complex matrix such as wine. The novelty of the proposed method compared to the conventional HPLC method with pre-column chemical derivatization is the approach for analysis of the biogenic amines, in which we avoided the derivatization time-consuming step, difficult sample preparation, and long run time for analysis. As a consequence of this approach, the main benefits are very fast, accurate, and short analysis of the amines in wine samples. The developed and validated method was applied for determination of BAs in various Macedonian red and white wines giving an overview on the nature and content of biogenic amines in wines from this region.

\section{Materials and Methods}

\section{Chemicals and Reagents}

Standards of biogenic amines used in the study were tryptamine (TRP), PUT, HIST, PEA, TYR, CAD, SPM, and SPD, all provided by Sigma-Aldrich (Munich, Germany), and 2phenylethylamine provided by Fluka (Munich, Germany). Water, methanol, ammonium formate, and formic acid (purity for LC/MS) were from Carlo Erba (Cornaredo, Italy). All other chemicals used were of analytical grade.

\section{Wine Samples}

In total, 34 wines, including 15 white, 17 red, and 2 rose wines produced in the Tikveš wine region (latitude $41^{\circ} 25^{\prime} 57^{\prime \prime} \mathrm{N}$ and longitude $22^{\circ} 05^{\prime} 11^{\prime \prime}$ E) (Republic of Macedonia), vintage 2015, were analyzed. Wine sample abbreviations were as follows for the white wines: W1 (Grenache Blank), W2 (Belan \& Chardonnay), W3 (Temjanika), W4 (Temjanika), W5 (Belan \& Chardonnay), W6 (Muscat Otonel), W7 (Riesling), W8 (Smederevka), W9 (Sauvignon Blank), W10 (Italian Riesling), W11 (Traminec), W12 (Žilavka), W13 (Rkaciteli), W14 (Chardonnay), and W15 (Chardonnay \& Riesling); the 
red wines were marked as R1 (Plavec), R2 (Vranec), R3 (Kadarka), R4 (Kratošija \& Merlto), R5 (Pinot Noir), R6 (Merlot \& Vranec), R7 (Vranec), R8 (Vranec \& Cabernet Sauvignon), R9 (Cabernet Sauvingnon), R10 (Vranec, sweet wine), R11 (Kadarka), R12 (Vranec \& Plavec), R13 (Kratošija), R14 (Vranec \& Kratošija), R15 (Merlot), R16 (Sirah), and R17 (Vranec \& Merlot \& Cabernet Sauvignon); and rose wines as were marked as Rose 1 (Pinot Noir \& Merlot $\&$ Cabernet Sauvignon) and Rose 2 (Kratošija). All wines were kept at $4{ }^{\circ} \mathrm{C}$ before analysis.

Before the UPLC-TQ-MS analysis, wines were diluted with $0.1 \%(v / v)$ formic acid in ratio $1: 3$ and filtrated with $0.45-\mu \mathrm{m}$ filter (Agilent PTFE).

\section{UPLC-TQ/MS Analysis}

The instrumentation used in this study was an Agilent UPLC 1290 system consisted of a binary pump 1290 Infinity G4220A, autosampler 1290 G4226A, column compartment $1260 \mathrm{G} 1316 \mathrm{~A}$, and detector DAD VL Agilent 1260 G1315D (Waldbronn, Germany), coupled with Agilent triple quadrupole LC/MS detector 6420 (Agilent Technologies, Santa Clara, CA, USA). Separation of the biogenic amines was achieved on Agilent Zorbax C18 Plus column $(100 \times 2.1 \mathrm{~mm}, 1.8-\mu \mathrm{m}$ particle size $)$, dedicated for rapid and high-pressure analysis up to 1200 bar. The mobile phase used consisted of solvent A, $5 \mathrm{mmol}$ ammonium formate and $0.1 \%(v / v)$ formic acid, and solvent B, methanol with $5 \mathrm{mmol}$ ammonium formate and $0.1 \%(v / v)$ formic acid, at flow rate of $0.2 \mathrm{~mL} / \mathrm{min}$. The gradient elution program was as follows: 0 $0.05 \mathrm{~min}, 20 \%$; 3.00-3.50 min, 80\%; and 3.75-5 min, $20 \%$. Total run time was $5 \mathrm{~min}$ and post-run time was $1 \mathrm{~min}$. The injection volume was $1 \mu \mathrm{L}$.

In addition, an Agilent HILIC Plus column $(100 \times 2.1 \mathrm{~mm}$, $1.8-\mu \mathrm{m}$ particle size) (Hydrophilic Interaction Liquid
Chromatography) column was tested for separation of biogenic amines. Mobile phase for separation of biogenic amines on this column composed of solvent A: $0.5 \mathrm{mmol}$ ammonium formate and $0.1 \%(v / v)$ formic acid and solvent B: acetonitrile with $0.1 \%(v / v)$ formic acid. The gradient program was as follows: $0-0.05 \mathrm{~min}, 90 \%$; $6.00-7.00 \mathrm{~min}, 20 \% \mathrm{~B}$; and $7.50-10 \mathrm{~min}, 90 \% \mathrm{~B}$ with a flow rate of $0.4 \mathrm{~mL} / \mathrm{min}$.

The tandem MS/MS conditions for determination of biogenic amines were optimized on the Agilent 6420 triple quadrupole mass spectrometer. Mass Hunter software (v. B.06.00) was used for instrument control, data acquisition, and evaluation. The applied parameters were capillary temperature $350{ }^{\circ} \mathrm{C}$, gas flow $12 \mathrm{~L} / \mathrm{min}$, nebulizer 15 psi, capillary voltage $3500 \mathrm{~V}$ in positive ionization mode, peak width $0.07 \mathrm{~min}$, cycle time $500 \mathrm{~ms}$, minimum data point 64 , and minimum and maximum dwell time 25.9 and $246.5 \mathrm{~ms}$, respectively.

The optimal quantification and confirmation transitions, their respective fragmentor, collision energies, cell accelerator voltage, polarity, and retention time with delta retention time windows are listed in Table 1. Mass Hunter Optimization Software was used for the Multiple Reaction Monitoring (MRM) optimization purposes. Automatically generated Dynamic Multiple Reaction Monitoring (DMRM) mode was used for precursor and product ion retention windows.

\section{Calibration Curves}

Stock solutions $(1 \mathrm{mg} / \mathrm{mL})$ of each biogenic amine (tryptamine, 2-phenyethylamine, putrescine, cadaverine, spermine, spermidine, tyramine, and histamine) were prepared in $0.1 \%(v / v)$ formic acid in water. For quantification, seven-point calibration curves were constructed in a range from 10 to $1000 \mu \mathrm{g} / \mathrm{L}$ for all amines, except for spermine (concentration range 100-2000 $\mu \mathrm{g} / \mathrm{L}$ ) (Table 2). For evaluation of the effect of wine matrix, the same series of standard

Table 1 Multiple Reaction Monitoring (MRM) conditions optimized for Agilent Triple Quad MS 6420 analysis for biogenic amines

\begin{tabular}{|c|c|c|c|c|c|c|c|c|c|c|}
\hline $\begin{array}{l}\text { Biogenic } \\
\text { amine }\end{array}$ & $\begin{array}{c}\text { Structural } \\
\text { formula }\end{array}$ & $\begin{array}{c}\text { Precursor } \\
\text { ion } \\
{\left[\mathbf{M}+\mathbf{H}^{+}\right]}\end{array}$ & $\begin{array}{c}\text { Product } \\
\text { Ion } 1 \\
(m / z) \\
\end{array}$ & $\begin{array}{c}\text { Product } \\
\text { Ion } 2 \\
(\mathrm{~m} / \mathrm{z})\end{array}$ & $t_{\mathrm{R}} /(\min )$ & $\begin{array}{c}\text { Delta } \\
t_{\mathrm{R}} /(\mathrm{min}\end{array}$ & Fragmentor & $\begin{array}{c}\text { Collision } \\
\text { Energy }\end{array}$ & $\begin{array}{c}\text { Cell } \\
\text { Accelerator } \\
\text { Voltage } \\
\end{array}$ & Polarity \\
\hline PEA & & 122 & 105 & 77 & 2.78 & 1.78 & 70 & $9 \& 33$ & 4 & Positive \\
\hline CAD & & 103 & 86 & / & 1.24 & 3.49 & 65 & $9 \& 5$ & 4 & Positive \\
\hline HIST & & 112 & 95 & 68 & 1.24 & 1.81 & 80 & $13 \& 21$ & 4 & Positive \\
\hline PUT & & 89 & 72 & I & 1.25 & 2.67 & 45 & 9 & 4 & Positive \\
\hline SPD & & 146 & 103 & 72 & 1.19 & 2.53 & 75 & $13 \& 13$ & 4 & Positive \\
\hline SPM & & 203 & 112 & 129 & 1.26 & 2.47 & 100 & $9 \& 17$ & 4 & Positive \\
\hline TRP & & 161 & 144 & 117 & 3.05 & 1.90 & 70 & $9 \& 25$ & 4 & Positive \\
\hline TYR & & 138 & 121 & 77 & 1.75 & 1.97 & 70 & $9 \& 29$ & 4 & Positive \\
\hline
\end{tabular}


Table 2 Range of determination, coefficients of the regression curves (slope), correlation coefficient $\left(R^{2}\right)$, coefficients of the regression curves in matrix, correlation coefficient $\left(R^{2}\right)$ in matrix, LOD, LOQ, and results for repeatability and reproducibility of biogenic amines $(\mu \mathrm{g} / \mathrm{L})$ in red wine $(\mathrm{R} 7)$

\begin{tabular}{|c|c|c|c|c|c|c|c|c|}
\hline $\begin{array}{l}\text { Biogenic } \\
\text { amines }\end{array}$ & $\begin{array}{l}\text { Calibration } \\
\text { range }(\mu \mathrm{g} / \mathrm{L})\end{array}$ & Slope & $R^{2}$ & $\mathrm{LOD}(\mu \mathrm{g} / \mathrm{L})$ & $\mathrm{LOQ}(\mu \mathrm{g} / \mathrm{L})$ & Matrix slope & Matrix $R^{2}$ & SSE $(\%)$ \\
\hline SPD & $10-1000$ & 203 & 0.9969 & 3.00 & 9.00 & 192 & 0.9975 & 95.1 \\
\hline HIST & $10-1000$ & 466 & 0.9998 & 0.50 & 1.50 & 422 & 0.9949 & 90.6 \\
\hline CAD & $10-1000$ & 85.8 & 0.9957 & 3.00 & 9.00 & 112 & 0.9953 & 131 \\
\hline PUT & $10-1000$ & 85.2 & 0.9906 & 4.00 & 12.0 & 96.8 & 0.9958 & 114 \\
\hline SPM & $100-2000$ & 258 & 0.9997 & 30.0 & 90.0 & 102 & 0.9906 & 39.2 \\
\hline TYR & $10-1000$ & 292 & 0.9979 & 1.00 & 3.00 & 342 & 0.9998 & 116 \\
\hline PEA & $10-1000$ & 572 & 0.9998 & 1.00 & 3.00 & 575 & 0.9997 & 100 \\
\hline TRP & $10-1000$ & 410 & 0.9979 & 0.50 & 1.50 & 450 & 0.9988 & 109 \\
\hline
\end{tabular}

SSE signal suppression enhancement, $L O D$ limit of detection, $L O Q$ limit of quantification

solutions was prepared using dilution in half volume of red wine $(0.5 \mathrm{~mL}$ red wine in $1 \mathrm{~mL}$ standard solution).

\section{Statistical Analysis}

Statistical treatment, including calculation of mean, relative standard deviation, standard error, and one-way ANOVA, were performed with STATISTICA 6.0 software (Stat Soft Inc., USA). Principal component analysis (PCA) was employed to evaluate the possible grouping of the wines, using XLSTAT Software, version 7.5.2, Addinsoft (Paris, France).

\section{Results and Discussion}

\section{UPLC-Triple Quadruple MS Identification of Biogenic Amines}

The UPLC-TQ/MS technique was used for separation and detection of the following biogenic amines: PEA, CAD, HIST, PUT, SPM, SPD, TRP, and TYR (Table 1). The assignment of the individual compounds in the wines was carried out by comparing with the MS/MS data obtained for the standards, analyzed under the same experimental conditions, and also those found in literature (Sagratini et al. 2012; Daniel et al. 2015). Characterization of the mass spectra was performed by injection of a standard solution of each biogenic amine, with concentration of $1000 \mu \mathrm{g} / \mathrm{L}$. All biogenic amines had similar fragmentation pattern, obtaining $\mathrm{m} / \mathrm{z}$ signal that corresponds to the protonated molecule $[\mathrm{M}+\mathrm{H}]^{+}$or precursor ion $\mathrm{m} / \mathrm{z}$, as follows: for 2-phenylethylamine at $\mathrm{m} / \mathrm{z}, 122$ (fragment ions at $\mathrm{m} / \mathrm{z}, 105$ and 77), cadaverine at $\mathrm{m} / \mathrm{z}, 103$ (fragment ion at $\mathrm{m} / \mathrm{z}, 86$ ), histamine at $\mathrm{m} / \mathrm{z}, 112$ (fragment ions at $\mathrm{m} / \mathrm{z}, 95$ and 68), putrescine at $\mathrm{m} / \mathrm{z} 89$ (fragment ion at $\mathrm{m} / \mathrm{z}, 72$ ), spermidine at $\mathrm{m} / z, 146$ (fragment ions at $\mathrm{m} / z, 103$ and 72), spermine at $m / z 203$ (fragment ions at $m / z 112$ and 129), tryptamine at $\mathrm{m} / \mathrm{z}, 161$ (fragment ions at $\mathrm{m} / \mathrm{z}, 144$ and 177), and
TYR at $m / z 138$ (fragment ions at $m / z 121$ and 77). For the six of eight amines, i.e., cadaverine, histamine, 2-phenylethylamine, putrescine, tyramine, and tryptamine, the main product ion used for quantification (the "quantifier") was generated by loss of a neutral ammonia molecule with $\mathrm{m} / \mathrm{z} 17$ [M+H$\left.\mathrm{NH}_{3}\right]^{+}$(Sagratini et al. 2012). The product ion of spermidine was giving a signal at $m / z 103$, while the quantifier ion for spermine at $\mathrm{m} / \mathrm{z}, 112$ corresponded to the loss of a larger fragment explained as $\left[\mathrm{M}+\mathrm{H}-\left(\mathrm{CH}_{2}\right)_{3} \mathrm{~N}_{2} \mathrm{H}_{4}-\mathrm{NH}_{3}\right]^{+}$(Sagratini et al. 2012). Putrescine and cadaverine produced only one product ion at $\mathrm{m} / z, 72$ and 86 , respectively, and additional optimization did not result in obtaining another ions.

\section{Optimization of the Chromatographic Conditions for Separation of Biogenic Amines}

For separation of the biogenic amines, two different columns were tested in the preliminary experiments: Agilent Zorbax C18 Plus $(100 \times 2.1 \mathrm{~mm}, 1.8-\mu \mathrm{m}$ particle size $)$ and Agilent Zorbax HILIC Plus $(100 \times 2.1 \mathrm{~mm}, 1.8-\mu \mathrm{m}$ particle size $)$, both dedicated for rapid and high-pressure analysis. The difference between these columns was the stationary phase; Zorbax contains stationary phase with octadecyl chains (C18)-bonded silica (Fig. 1a), while HILIC contains a normal phase stationary phase using mobile phase conditions same as for reversed phase columns (Fig. 1b). Even both columns exhibited satisfactory peak shapes of the analytes, the peak of spermine (1) had more intensive tailing peak shape on the HILIC column compared to the Zorbax column. Also, the total run time was twofold shorter when Zorbax column (5 min) was used for separation of the biogenic amines, compared to HILIC column (10 min). Therefore, Zorbax column, presenting good peak shapes, satisfactory resolution, and short analysis time (5 min), was selected for further analyses, including optimization of method parameters, validation, and application on real wine samples. Figure 2 presents the ion extracted chromatograms of biogenic amines in Vranec wine (R2). 

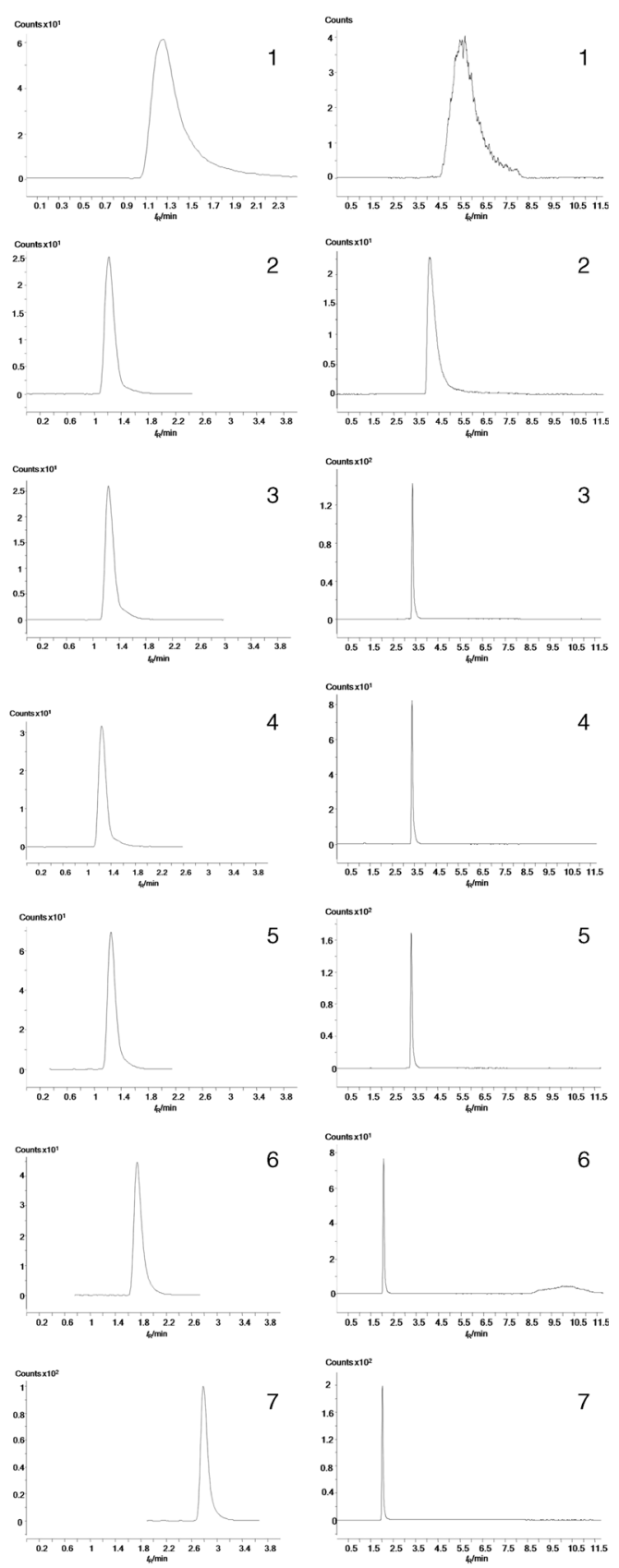

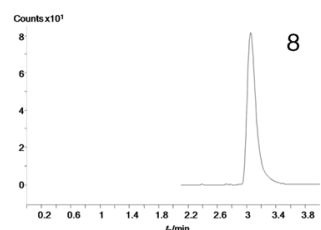

A

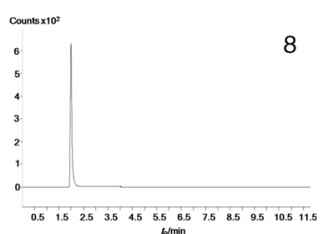

B
Fig. 1 UPLC-TQ/MS ion extracted chromatogram biogenic amines in a standard solution obtained on two columns. a Zorbax C18 Plus column (run time $5 \mathrm{~min}$ ). b HILIC Plus column (run time $10 \mathrm{~min}$ ). Peak assignment spermine (1), spermidine (2), cadaverin (3), putrescine (4), histamine (5), tyramine (6), 2-phenylethylamine (7), tryptamine (8)

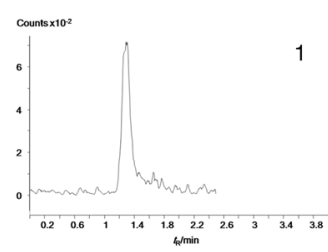

Counts $\times 10^{-3}$
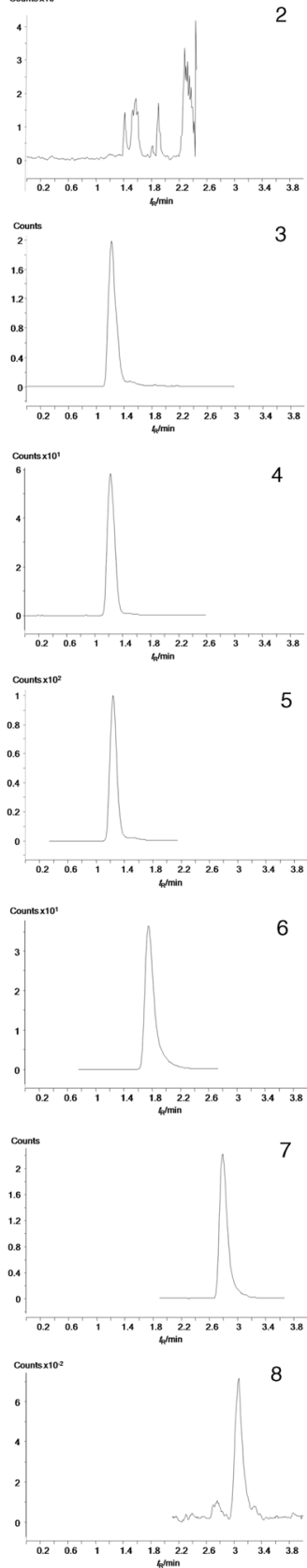

Fig. 2 UPLC-TQ/MS ion extracted chromatogram biogenic amines in wine (Vranec) on Zorbax C18 Plus column. Peak assignment spermine (1), spermidine (2), cadaverin (3), putrescine (4), histamine (5), tyramine (6), 2-phenylethylamine (7), tryptamine (8) 
In order to study the effect of ionization efficiency, different concentrations of ammonium formate $(0.5,1,1.5,2$, and $2.5 \mathrm{mmol} / \mathrm{L})$ and formic acid $(0.05,0.1,1,1.5,2,2.5,3 \%$ $(v / v))$ added in the mobile phase were tested. Increasing the concentration of ammonium formate in the mobile phase led to a reduction of the peak areas, especially evident for the spermine (data not shown). Therefore, a concentration of $0.5 \mathrm{mmol} / \mathrm{L}$ of ammonium formate in the mobile phase was chosen for the analysis. The influence of the mobile phase acidity on biogenic amines was also checked. Lower peak intensities were obtained with $0.05 \%$ formic acid in the mobile phase presumably due to the insufficient ionization of the molecules under these conditions. Using $0.1 \%$ formic acid in the mobile phase allowed best molecule ionization. From these data, $0.5 \mathrm{mmol} / \mathrm{L}$ of ammonium formate and $0.1 \%$ formic acid in the mobile phase were the best compromise for simultaneous analysis of biogenic amines in wine.

The effect of the wine matrix on the ionization and thus sensitivity for quantification of the tested biogenic amines was also studied using Vranec wine sample (R2). For this purpose, calibration standards were prepared and measured in the wine matrix (R2) with standard additions of all investigated biogenic amines. Slopes and correlation coefficients were then calculated for these calibration curves and compared to the ones prepared in $0.1 \%$ formic acid in water, without the wine matrix (Table 2). To evaluate the matrix effect, the signal suppression enhancement (SSE) was calculated as the ratio of the slope of the standards in wine matrix and the slope of the standards prepared without matrix for each biogenic amine studied (Sagratini et al. 2012).

$\mathrm{SSE}=($ slope matrix matched calibration/slope standard calibration in solvent $) \times 100$

From the results presented in Table 2, it can be seen that wine matrix has diverse influence on each biogenic amine causing enhancing or suppression of the process of ionization that is expressed by the signal suppression enhancement calculated in percent. Values higher than $100 \%$ mean higher slopes with matrix that are due to signal enhancement and more efficient ionization, whereas $\mathrm{SSE}<100 \%$ is due to ionization suppression in the presence of the matrix. A negative influence and ionization suppression causing decrease of the signals was observed for spermidine (SSE 95.1) and histamine (SSE 90.6), whereas increased signals were observed for cadaverine (SSE 131), putrescine (SSE 114), tyramine (SSE 116), and tryptamine (SSE 109), and no influence was observed for 2phenylethylamine (SSE 100). The wine matrix caused most severe suppression of the signal of spermine where suppression was greater than $60 \%$ (SSE 39). So, the proposed method can be successfully used for all biogenic amines, with standard calibration curves in aqueous solvent, except for spermine where the negative matrix effect, i.e., ionization suppression, has to be taken into account and the measurements should be made using calibration standards prepared in wine matrix.

In fact, the main advantage of the proposed method is analysis of the biogenic amines in wine without derivatization. In that way, the analysis is simpler and faster (only dilution of wine is performed) compared to the HPLC-DAD method, whereas derivatization step is necessary to be performed prior the HPLC analysis (Tašev et al. 2016).

\section{Validation of the Method}

Linearity was tested in 3 days at seven concentration levels. The linearity data, including slope, intercept, and correlation coefficient $\left(R^{2}\right)$, were calculated, and they are presented in Table 2. As it can be seen from the table, the linearity is satisfactory in all cases with correlation coefficients $\left(R^{2}>0.99\right.$ ), ranging from 0.9957 for cadaverine to 0.9998 for histamine and 2-phenylethylamine.

Limit of detection (LOD) was determined as a concentration of the analyte that gives a signal equal to the average background $\left(S_{\text {blank }}\right)$ plus three times the standard deviation of the blank $\left(s_{\text {blank }}\right)$ LOD $=S_{\text {blank }}+3 \times\left(s_{\text {blank }}\right)$, and limit of quantification (LOQ) was determined as $\mathrm{LOQ}=3 \times \mathrm{LOD}$. The obtained values for LOD and LOQ ranged from 0.50 to $30.0 \mu \mathrm{g} / \mathrm{L}$ and 1.50 to $90.0 \mu \mathrm{g} / \mathrm{L}$, respectively, for all amines. The lowest limits of detection were noticed for histamine and tryptamine with $0.50 \mu \mathrm{g} / \mathrm{L}$, followed by tyramine and 2phenylethylamine with LOD $1.00 \mu \mathrm{g} / \mathrm{L}$, then spermidine and cadaverine with $3.00 \mu \mathrm{g} / \mathrm{L}$, and putrescine with $4.00 \mu \mathrm{g} / \mathrm{L}$, and the highest LOD was found for spermine with $30 \mu \mathrm{g} / \mathrm{L}$ (Table 2).

\section{Accuracy and Precision}

The intra-day and inter-day accuracy and precision were determined by injection of standard solutions with low $(40 \mu \mathrm{g} / \mathrm{L})$, medium $(100 \mu \mathrm{g} / \mathrm{L})$, and high concentrations $(500 \mu \mathrm{g} / \mathrm{L})$ of all tested biogenic amines: tryptamine, 2phenyethylamine, putrescine, cadaverine, spermine, spermidine, tyramine, and histamine. For determination of intra-day accuracy and precision, freshly prepared solutions were used, analyzed immediately, in three repetitions during 1 day. Inter-day accuracy and precision were determined during three consecutive days with three repeated analyses. The results are presented in Table 3. 
Table 3 Inter- and intra-day accuracy and precision and standard addition method for checking the accuracy on real samples

\begin{tabular}{|c|c|c|c|c|c|c|c|c|c|c|c|c|c|}
\hline \multicolumn{2}{|c|}{ Standard additions } & \multicolumn{4}{|c|}{ STD I $(40 \mu \mathrm{g} / \mathrm{L})$} & \multicolumn{4}{|c|}{ STD II $(100 \mu \mathrm{g} / \mathrm{L})$} & \multicolumn{4}{|c|}{ STD III $(500 \mu \mathrm{g} / \mathrm{L})$} \\
\hline $\begin{array}{l}\text { Biogenic } \\
\text { amines }\end{array}$ & $\begin{array}{l}\text { Concentration } \\
\text { in wine } \\
(\mu \mathrm{g} / \mathrm{L})\end{array}$ & $<x>$ & $\mathrm{SD}$ & $\operatorname{RSD}(\%)$ & Recovery $(\%)$ & $<x>$ & SD & $\operatorname{RSD}(\%)$ & Recovery $(\%)$ & $<x>$ & $\mathrm{SD}$ & $\mathrm{RSD}(\%)$ & $\begin{array}{c}\text { Recovery } \\
(\%)\end{array}$ \\
\hline \multicolumn{14}{|c|}{ Inter-day accuracy and precision (three replicates in 1 day) and recovery } \\
\hline SPD & 68.5 & 107 & 3.27 & 3.05 & 101 & 181 & 7.25 & 3.99 & 93.1 & 507 & 23.2 & 4.58 & 112 \\
\hline CAD & 76.8 & 121 & 0.71 & 0.58 & 96.5 & 182 & 2.23 & 1.22 & 97.1 & 576 & 5.64 & 0.98 & 100 \\
\hline PUT & 199 & 236 & 10.0 & 0.56 & 101 & 334 & 8.77 & 0.48 & 89.5 & 738 & 14.1 & 0.78 & 94.7 \\
\hline HIST & 51.5 & 92.2 & 0.98 & 1.07 & 99.2 & 164 & 2.94 & 1.79 & 92.4 & 635 & 10.9 & 1.71 & 86.9 \\
\hline SPM & $<\mathrm{LOQ}$ & $<\mathrm{LOQ}$ & - & - & - & 103 & 0.41 & 0.40 & 103 & 522 & 4.66 & 0.89 & 104 \\
\hline TYR & 37.9 & 79.7 & 2.92 & 5.72 & 97.7 & 147 & 2.54 & 1.72 & 93.8 & 593 & 9.60 & 1.62 & 90.7 \\
\hline PEA & 40.9 & 84.5 & 0.97 & 1.14 & 95.7 & 151 & 2.43 & 1.61 & 93.3 & 600 & 3.51 & 0.58 & 90.2 \\
\hline TRP & $<\mathrm{LOQ}$ & 37.8 & 0.00 & 0.00 & 94.5 & 98.5 & 6.74 & 1.35 & 98.5 & 501 & 6.74 & 1.35 & 100 \\
\hline \multicolumn{14}{|c|}{ Intra-day accuracy and precision (three replicates in three different days) } \\
\hline SPD & 68.5 & 108 & 3.28 & 3.05 & 100 & 183 & 7.28 & 3.99 & 92.1 & 509 & 23.3 & 4.58 & 112 \\
\hline CAD & 76.8 & 122 & 0.71 & 0.58 & 95.7 & 183 & 2.24 & 1.22 & 96.6 & 579 & 5.66 & 0.98 & 100 \\
\hline PUT & 199 & 238 & 10.1 & 0.56 & 100 & 334 & 8.81 & 0.48 & 89.5 & 740 & 14.1 & 0.78 & 94.5 \\
\hline HIST & 51.5 & 92.7 & 0.99 & 1.07 & 98.7 & 164 & 2.95 & 1.79 & 92.4 & 638 & 10.9 & 1.71 & 86.4 \\
\hline SPM & $<\mathrm{LOQ}$ & $<\mathrm{LOQ}$ & - & - & - & 103 & 0.41 & 0.40 & 103 & 525 & 2.7 & 4.69 & 105 \\
\hline TYR & 37.9 & 80.1 & 2.94 & 3.67 & 97.3 & 148 & 2.56 & 1.72 & 93.2 & 596 & 9.65 & 1.72 & 90.3 \\
\hline PEA & 40.9 & 84.9 & 0.97 & 1.14 & 95.3 & 152 & 2.44 & 1.61 & 92.7 & 603 & 3.53 & 0.58 & 89.7 \\
\hline TRP & $<\mathrm{LOQ}$ & 38.0 & 0.00 & 0.00 & 95.0 & 99.0 & 4.18 & 4.22 & 99 & 503 & 6.77 & 1.35 & 101 \\
\hline
\end{tabular}

STD standard addition, $<x>$ average value, $S D$ standard deviation, $R S D$ relative standard deviation, $L O Q$ limit of quantification

The accuracy was expressed with the recovery of the determined concentration compared with the true (nominal) value. It was checked using the standard addition method on real wine sample (Vranec). Red wine sample was spiked at three concentration levels with mixed standard solution of biogenic amines with low $(40 \mu \mathrm{g} / \mathrm{L})$, medium $(100 \mu \mathrm{g} / \mathrm{L})$, and high concentrations $(500 \mu \mathrm{g} / \mathrm{L})$. The analysis of these spiked samples led to calculated recoveries ranging between 90.2 and $112 \%$ (Table 3), which confirmed the accuracy of the method and its suitability for analysis of biogenic amines in wine samples.

Precision was expressed as a relative standard deviation $(R S D)$. Obtained values for $R S D$ were lower than $5 \%$ for all amines, except for tyramine (RSD was $5.72 \%$ for the low standard addition with concentration of $40 \mu \mathrm{g} / \mathrm{L}$ ), which confirmed that the proposed method is precise.

\section{Repeatability and Reproducibility}

Repeatability was checked with six repetitions in 1 day, while reproducibility was checked with three repetitions in five consecutive days, both performed on a real red wine sample. Values for the relative standard deviation were very low, ranging from 0.43 to $7.89 \%$ for repeatability and 0.36 to $7.56 \%$ for reproducibility, the highest ones obtained for spermine, whereas all others were below $3 \%$, confirming that the method is reproducible and can be applied for determination of biogenic amines in white and red wines (data not shown).

\section{Biogenic Amines Content in Red and White Wines}

The optimized and validated UPLC-TQ/MS method was applied for analysis of biogenic amines in Macedonian white and red wines from various varieties. The content of the determined biogenic amines in the wines is presented in Table 4.

Biogenic amines were detected in all analyzed wines since they are naturally present in wine, and it is very difficult, or even impossible, to obtain a wine that does not contain any biogenic amines. Among all biogenic amines, histamine was the most abundant in all wines, ranging from 14.9 to $67.4 \mu \mathrm{g} / \mathrm{L}$ in white wines and from 42.5 to $5131 \mu \mathrm{g} / \mathrm{L}$ in red wines. Four wines (R6 Merlot \& Vranec, R7 Vranec, R9 Cabernet Sauvingnon, and R17 Vranec \& Merlot \& Cabernet Sauvignon) contained histamine in a higher concentration $(4.1,5.1,2.7$, and $4.5 \mathrm{~g} / \mathrm{L}$, respectively) than the recommended values of $2 \mathrm{mg} / \mathrm{L}$ (Maintz and Novak 2007; Spano et al. 2010). The other biogenic amines (tyramine, 2phenyethylamine, and tryptamine) in white wines were in the range of $12.0-22.4 \mu \mathrm{g} / \mathrm{L}$ for tyramine, $16.9-138 \mu \mathrm{g} / \mathrm{L}$ for 2-phenyethylamine, and 3.69-5.68 $\mu \mathrm{g} / \mathrm{L}$ for tryptamine, while in red wines, they ranged from 183 to $6538 \mu \mathrm{g} / \mathrm{L}$ for tyramine, 59.4-1001 $\mu \mathrm{g} / \mathrm{L}$ for 2-phenyethylamine, and 2.27- 
Table 4 Content of biogenic amines in Macedonian wines given in $\mu \mathrm{g} / \mathrm{L} \pm \operatorname{standard}$ deviation $(n=3)$

\begin{tabular}{|c|c|c|c|c|c|c|c|c|c|}
\hline Wines & SPD & CAD & PUT & HIST & SPM & TYR & PEA & TRP & $\Sigma$ \\
\hline \multicolumn{10}{|l|}{ White wines } \\
\hline W1 & $56.6 \pm 0.31 \mathrm{a}$ & $117 \pm 3.21$ & $1,444 \pm 10.54$ & $42.3 \pm 1.79 \mathrm{a}$ & $<\mathrm{LOQ}$ & $16.4 \pm 0.07 \mathrm{a}$ & $16.9 \pm 0.11$ & $5.46 \pm 0.63 \mathrm{a}$ & $1,706 \mathrm{a}$ \\
\hline W2 & $56.0 \pm 0.31 \mathrm{a}$ & $309 \pm 8.48 \mathrm{a}$ & $893 \pm 6.52$ & $46.2 \pm 1.96 \mathrm{a}$ & $<$ LOQ & $14.4 \pm 0.06 \mathrm{~b}$ & $80.4 \pm 0.53 \mathrm{a}$ & $4.38 \pm 0.50 \mathrm{~b}$ & 1,414 \\
\hline W3 & $55.7 \pm 0.30 \mathrm{a}$ & $388 \pm 10.6 \mathrm{c}$ & $1,007 \pm 7.35$ & $67.4 \pm 2.86$ & $<\mathrm{LOQ}$ & $13.0 \pm 0.05 \mathrm{~b}$ & $70.2 \pm 0.46$ & $3.94 \pm 0.45 \mathrm{c}$ & $1,622 \mathrm{~d}$ \\
\hline W4 & $505 \pm 2.75$ & $416 \pm 11.4$ & $669 \pm 4.88 \mathrm{~b}$ & $50.8 \pm 2.15 \mathrm{~b}$ & $<\mathrm{LOQ}$ & $19.0 \pm 0.08 \mathrm{c}$ & $80.7 \pm 0.53 \mathrm{a}$ & $4.39 \pm 0.50 \mathrm{~b}$ & $1,762 \mathrm{a}$ \\
\hline W5 & $711 \pm 3.88$ & $193 \pm 5.29$ & $741 \pm 5.41$ & $56.7 \pm 2.41 \mathrm{~b}$ & $<\mathrm{LOQ}$ & $18.5 \pm 0.08 \mathrm{c}$ & $77.5 \pm 0.51 \mathrm{a}$ & $5.43 \pm 0.62 \mathrm{a}$ & 1,813 \\
\hline W6 & $143 \pm 0.78$ & $152 \pm 4.16$ & $753 \pm 5.31$ & $45.4 \pm 1.93 \mathrm{a}$ & $<\mathrm{LOQ}$ & $18.1 \pm 0.08 \mathrm{c}$ & $25.8 \pm 0.17 b$ & $5.68 \pm 0.65 \mathrm{a}$ & $1,137 \mathrm{~b}$ \\
\hline W7 & $60.0 \pm 0.33 \mathrm{a}, \mathrm{b}$ & $724 \pm 19.8$ & $762 \pm 5.56$ & $50.6 \pm 2.15 \mathrm{~b}$ & $<\mathrm{LOQ}$ & $15.1 \pm 0.06 \mathrm{a}$ & $92.0 \pm 0.61$ & $5.55 \pm 0.64 \mathrm{a}$ & 1,728 \\
\hline W8 & $57.0 \pm 0.31 \mathrm{a}$ & $290 \pm 7.96 \mathrm{a}$ & $820 \pm 5.99 \mathrm{a}$ & $38.1 \pm 1.61 \mathrm{a}$ & $<\mathrm{LOQ}$ & $15.9 \pm 0.07 \mathrm{a}$ & $133 \pm 0.88$ & $5.08 \pm 0.58 \mathrm{a}$ & $1,368 \mathrm{c}$ \\
\hline W9 & $113 \pm 0.62$ & $175 \pm 4.81 \mathrm{~d}$ & $815 \pm 5.95 \mathrm{a}$ & $28.3 \pm 1.20$ & $<\mathrm{LOQ}$ & $22.4 \pm 0.09$ & $35.4 \pm 0.21$ & $4.74 \pm 0.54 b$ & $1,200 \mathrm{~b}$ \\
\hline W10 & $59.2 \pm 0.32 \mathrm{a}$ & $650 \pm 17.8$ & $786 \pm 5.74 \mathrm{a}$ & $52.3 \pm 2.22 b$ & $<\mathrm{LOQ}$ & $14.1 \pm 0.06 b$ & $63.3 \pm 0.42 \mathrm{c}$ & $4.51 \pm 0.52 b$ & $1,644 \mathrm{~d}$ \\
\hline W11 & $133 \pm 0.73$ & $457 \pm 12.5 \mathrm{~b}$ & $782 \pm 5.71 \mathrm{a}$ & $55.0 \pm 2.33 \mathrm{~b}$ & $<\mathrm{LOQ}$ & $15.3 \pm 0.06 \mathrm{a}$ & $85.3 \pm 0.56 \mathrm{~d}$ & $4.17 \pm 0.48 c$ & 1,544 \\
\hline W12 & $59.7 \pm 0.33 \mathrm{a}$ & $330 \pm 9.03 \mathrm{c}$ & $1,121 \pm 8.18$ & $27.8 \pm 1.18$ & $<\mathrm{LOQ}$ & $13.2 \pm 0.06 \mathrm{~b}$ & $138 \pm 0.91$ & $4.56 \pm 0.52 b$ & $1,705 \mathrm{a}$ \\
\hline W13 & $65.3 \pm 0.36 b$ & $173 \pm 4.73 \mathrm{~d}$ & $556 \pm 4.06$ & $14.9 \pm 0.63$ & $<$ LOQ & $18.6 \pm 0.08 \mathrm{c}$ & $27.1 \pm 0.18 b$ & $5.45 \pm 0.63 \mathrm{a}$ & 866 \\
\hline W14 & $113 \pm 0.62$ & $484 \pm 13.3 b$ & $635 \pm 4.64 \mathrm{~b}$ & $38.3 \pm 1.62 \mathrm{a}$ & $<\mathrm{LOQ}$ & $12.0 \pm 0.05$ & $86.6 \pm 0.57 \mathrm{~d}$ & $4.00 \pm 0.46 \mathrm{c}$ & $1,385 \mathrm{c}$ \\
\hline W15 & $61.5 \pm 0.34 b$ & $313 \pm 8.59 \mathrm{a}$ & $885 \pm 6.46$ & $40.6 \pm 1.72 \mathrm{a}$ & $<\mathrm{LOQ}$ & $13.7 \pm 0.06 \mathrm{~b}$ & $63.3 \pm 0.42 \mathrm{c}$ & $3.69 \pm 0.42$ & $1,391 \mathrm{c}$ \\
\hline Average & 150 & 345 & 844 & 43.7 & $<\mathrm{LOQ}$ & 16.0 & 71.7 & 4.7 & 1,485 \\
\hline Range & $55.7-712$ & $117-724$ & $556-1,444$ & $14.9-67.4$ & $<\mathrm{LOQ}$ & $12.0-22.4$ & $16.9-138$ & $3.67-5.68$ & $866-1,813$ \\
\hline \multicolumn{10}{|l|}{ Red wines } \\
\hline R1 & $59.5 \pm 0.90 \mathrm{a}$ & $654 \pm 9.85 \mathrm{a}$ & $1,476 \pm 22.2$ & $138 \pm 2.08 \mathrm{a}$ & $<\mathrm{LOQ}$ & $6,538 \pm 98.4$ & $228 \pm 3.43 \mathrm{a}$ & $6.48 \pm 0.10$ & 9,111 \\
\hline R2 & $65.9 \pm 0.99 \mathrm{~b}$ & $383 \pm 5.77$ & $2,255 \pm 34.0 \mathrm{a}$ & $521 \pm 7.85$ & $<\mathrm{LOQ}$ & $2,704 \pm 40.7 \mathrm{a}$ & $157 \pm 2.37 \mathrm{~b}$ & $3.63 \pm 0.05 \mathrm{a}$ & $6,097 \mathrm{a}$ \\
\hline R3 & $55.7 \pm 0.84 \mathrm{a}$ & $639 \pm 9.63 \mathrm{a}$ & $2,116 \pm 31.9$ & $74.5 \pm 1.12 b$ & $<\mathrm{LOQ}$ & $2,642 \pm 39.8 \mathrm{a}$ & $283 \pm 4.26 \mathrm{a}$ & $5.30 \pm 0.08 \mathrm{c}$ & 5,827 \\
\hline R4 & $55.9 \pm 0.84 \mathrm{a}$ & $619 \pm 9.32$ & $1,867 \pm 28.1 b$ & $44.4 \pm 0.67 \mathrm{c}$ & $<\mathrm{LOQ}$ & $756 \pm 11.4 b$ & $97.1 \pm 1.46$ & $4.49 \pm 0.07 \mathrm{~b}$ & 3,452 \\
\hline R5 & $55.7 \pm 0.84 \mathrm{a}$ & $480 \pm 7.23 b$ & $1,192 \pm 18.0$ & $142.4 \pm 2.14$ & $<\mathrm{LOQ}$ & $802 \pm 12.1$ & $86.4 \pm 1.30 \mathrm{~b}$ & $4.94 \pm 0.07 \mathrm{~b}$ & $2,770 \mathrm{~d}$ \\
\hline R6 & $174 \pm 2.63$ & $495 \pm 7.46 \mathrm{~b}$ & $1,704 \pm 25.7 b$ & $4,163 \pm 62.7 \mathrm{~d}$ & $<\mathrm{LOQ}$ & $5,687 \pm 85.6$ & $165 \pm 2.48 \mathrm{c}$ & $3.98 \pm 0.06 \mathrm{a}$ & $12,410 \mathrm{~b}$ \\
\hline R7 & $63.7 \pm 0.96 \mathrm{~b}$ & $585 \pm 8.81$ & $1,923 \pm 29.0 \mathrm{~b}$ & $5,131 \pm 77.3$ & $<\mathrm{LOQ}$ & $4,364 \pm 65.7$ & $103 \pm 1.56$ & $4.36 \pm 0.07 b$ & $12,191 \mathrm{~b}$ \\
\hline $\mathrm{R} 8$ & $56.5 \pm 0.85 \mathrm{a}$ & $203 \pm 3.05$ & $210 \pm 3.21$ & $67.4 \pm 1.01 \mathrm{~b}$ & $<\mathrm{LOQ}$ & $912 \pm 13.7$ & $84.1 \pm 1.27 b$ & $2.27 \pm 0.03$ & 1,542 \\
\hline R9 & $100 \pm 1.51$ & $488 \pm 7.35 \mathrm{~b}$ & $2,397 \pm 36.1 \mathrm{a}$ & $2,731 \pm 41.1$ & $<\mathrm{LOQ}$ & $2,916 \pm 43.9 \mathrm{a}$ & $1,001 \pm 15.1$ & $15.9 \pm 0.24$ & 9,654 \\
\hline R10 & $58.6 \pm 0.88 \mathrm{a}$ & $837 \pm 12.6$ & $2,152 \pm 32.4 \mathrm{a}$ & $384 \pm 5.79$ & $<\mathrm{LOQ}$ & $715 \pm 10.8 b$ & $318 \pm 4.79$ & $5.93 \pm 0.09 \mathrm{c}$ & $4,481 \mathrm{c}$ \\
\hline R11 & $57.2 \pm 0.86 \mathrm{a}$ & $454 \pm 6.84 \mathrm{~b}$ & $2,363 \pm 35.6 \mathrm{a}$ & $57.2 \pm 0.86$ & $<\mathrm{LOQ}$ & $183 \pm 2.75$ & $59.4 \pm 0.89$ & $4.12 \pm 0.06 \mathrm{~b}$ & 3,187 \\
\hline $\mathrm{R} 12$ & $57.2 \pm 0.86 \mathrm{a}$ & $595 \pm 8.96$ & $1,961 \pm 29.5$ & $348 \pm 5.25$ & $<\mathrm{LOQ}$ & $3,025 \pm 45.5$ & $149 \pm 2.25 \mathrm{c}$ & $4.66 \pm 0.07 \mathrm{~b}$ & $6,151 \mathrm{a}$ \\
\hline $\mathrm{R} 13$ & $56.2 \pm 0.85 \mathrm{a}$ & $677 \pm 10.0 \mathrm{a}$ & $1,848 \pm 27.8 b$ & $125 \pm 1.89 \mathrm{a}$ & $<\mathrm{LOQ}$ & $2,975 \pm 44.8 \mathrm{a}$ & $348 \pm 5.24$ & $8.43 \pm 0.13$ & $6,046 \mathrm{a}$ \\
\hline R14 & $57.0 \pm 0.86 \mathrm{a}$ & $439 \pm 6.60 \mathrm{~b}$ & $1,619 \pm 24.4 \mathrm{c}$ & $107 \pm 1.62$ & $<\mathrm{LOQ}$ & $1,548 \pm 23.3$ & $193 \pm 2.91$ & $3.18 \pm 0.05$ & 3,970 \\
\hline R15 & $55.5 \pm 0.84 \mathrm{a}$ & $574 \pm 8.65 \mathrm{c}$ & $1,663 \pm 25.0 \mathrm{c}$ & $42.5 \pm 0.64 \mathrm{c}$ & $<\mathrm{LOQ}$ & $262 \pm 3.94$ & $86.4 \pm 1.30 \mathrm{~b}$ & $3.73 \pm 0.06 \mathrm{a}$ & $2,698 \mathrm{~d}$ \\
\hline R16 & $56.0 \pm 0.84 \mathrm{a}$ & $670 \pm 10.1 \mathrm{a}$ & $2,780 \pm 41.9$ & $239 \pm 3.60$ & $<\mathrm{LOQ}$ & $212 \pm 3.19$ & $109 \pm 1.64$ & $4.56 \pm 0.07$ & $4,081 \mathrm{c}$ \\
\hline $\mathrm{R} 17$ & $55.7 \pm 0.84 \mathrm{a}$ & $547 \pm 8.24 \mathrm{c}$ & $2,400 \pm 36.1 \mathrm{a}$ & $4,494 \pm 67.7 \mathrm{~d}$ & $<\mathrm{LOQ}$ & $757 \pm 11.4$ & $209 \pm 3.15$ & $3.26 \pm 0.05$ & 8,489 \\
\hline Average & 67.7 & 554 & 1,879 & 1,210 & $<\mathrm{LOQ}$ & 1,850 & 219 & 5.3 & 5,797 \\
\hline Range & $55.5-174$ & $203-837$ & $210-2,780$ & $42.5-5,131$ & $<\mathrm{LOQ}$ & $183-6,538$ & $59.4-1,001$ & $2.27-15.9$ & $1,542-12,4$ \\
\hline \multicolumn{10}{|l|}{ Rose wines } \\
\hline Rose 1 & $64.2 \pm 0.97 \mathrm{a}$ & $344 \pm 5.18$ & $961 \pm 14.5$ & $47.1 \pm 0.71 \mathrm{a}$ & $<$ LOQ & $50.9 \pm 0.77$ & $60.5 \pm 0.91$ & $2.43 \pm 0.04$ & $1,538 \mathrm{a}$ \\
\hline Rose 2 & $65.8 \pm 0.99 \mathrm{a}$ & $187 \pm 2.82$ & $865 \pm 13.0$ & $40.0 \pm 0.60 \mathrm{a}$ & $<\mathrm{LOQ}$ & $31.3 \pm 0.47$ & $32.1 \pm 0.48$ & $1.74 \pm 0.03$ & $1,231 \mathrm{a}$ \\
\hline Average & 65.0 & 266 & 913 & 43.5 & $<\mathrm{LOQ}$ & 41.1 & 46.3 & 2.1 & 1,385 \\
\hline Range & $64.2-65.8$ & $187-344$ & $865-961$ & $40.0-47.1$ & $<\mathrm{LOQ}$ & $31.3-50.9$ & $32.1-60.5$ & $1.74-2.43$ & $1,231-1,538$ \\
\hline
\end{tabular}

Same letters in the column indicate the values that are not significantly different $(p>0.05)$, analyzed by the ANOVA Tukey-Kramer multiple comparison test

$\leq L O Q$ value lower than the limit of quantification

W1 (Grenache Blank), W2 (Belan\&Chardonnay), W3 (Temjanika), W4 (Temjanika), W5 (Belan\&Chardonnay), W6 (Muscat Otonel), W7 (Risling), W8 (Smederevka), W9 (Sauvignon Blank), W10 (Italian Risling), W11 (Traminec), W12 (Žilavka), W13 (Rkaciteli), W14 (Chardonnay), W15 (Chardonnay\&Riesling)

R1 (Plavec), R2 (Vranec), R3 (Kadarka), R4 (Kratošija\&Merlto), R5 (Pinot Noir), R6 (Merlot\&Vranec), R7 (Vranec), R8 (Vranec\&Cabernet Sauvignon), R9 (Cabernet Sauvingnon), R10 (Vranec, sweet wine), R11 (Kadarka), R12 (Vranec\&Plavec), R13 (Kratošija), R14 (Vranec\&Kratošija), R15 (Merlot), R16 (Syrah), R17 (Vranec\&Merlot\&Cabernet Sauvignon), Rose 1 (Pinot Noir\&Merlot\&Cabernet Sauvignon), Rose 2 (Kratošija)

$15.9 \mu \mathrm{g} / \mathrm{L}$ for tryptamine. Putrescine and cadaverine were also found; putrescine was in the range from 210 to $2780 \mu \mathrm{g} / \mathrm{L}$ for red wines and 556 to $1444 \mu \mathrm{g} / \mathrm{L}$ for white wines, and cadaverine 203 to $837 \mu \mathrm{g} / \mathrm{L}$ and 117 to $724 \mu \mathrm{g} / \mathrm{L}$ for the red and white wines, respectively. Spermidine was present in a low range in both red (55.5-174 $\mu \mathrm{g} / \mathrm{L})$ and white wines (55.7 to $711 \mu \mathrm{g} / \mathrm{L}$ ), while spermine was below the LOQ for all wines.
These results corresponded to other reported results for biogenic amines in wines (Daniel et al. 2015). In general, the sum of the concentration of all determined biogenic amines in red wines was significantly higher $(5797 \mu \mathrm{g} / \mathrm{L}$, on average) compared to the white wines $(1485 \mu \mathrm{g} / \mathrm{L}$, on average). The variability in the BA content between red and white wines could be associated to different vinification techniques, such as the 


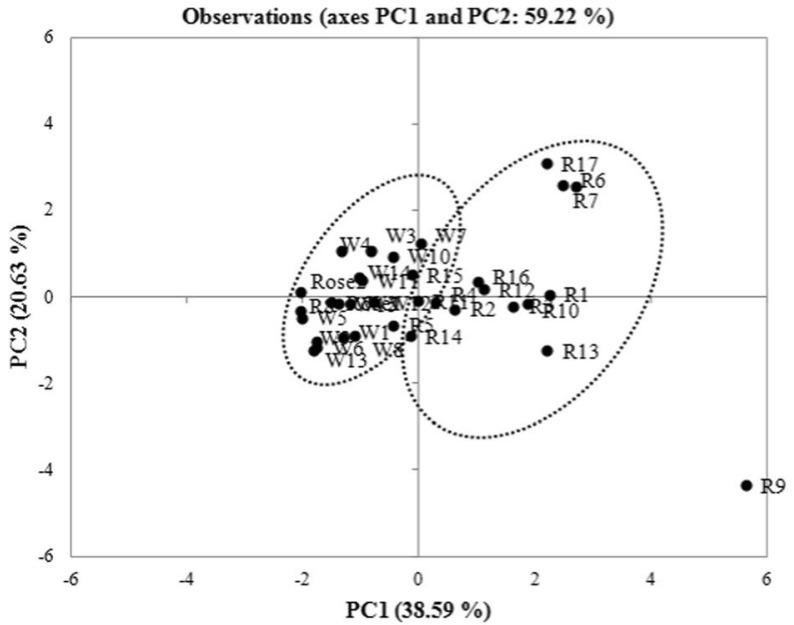

A

Fig. 3 a Correlation scatter plot of wine classification in function of PC1 and PC2, for all the analyzed variables. b PCA loadings of all analysed

must contact time with grape skins that is applied for red winemaking or amino acids content at the initial and final phases of alcoholic fermentation.

In general, analyzed Macedonian wines contained low amount of biogenic amines and their concentrations would not have negative effect on consumers' health, which means that both red and white wines were safe for consumption with regards to the biogenic amines (Soufleros et al. 1998; Martuscelli et al. 2013).

\section{Principal Component Analysis}

Principal component analysis (PCA) was applied using the dataset of individual biogenic amines obtained from the UPLC-TQ/MS analysis. PCA was used to explore the effect of grape variable (red vs. white) based on the biogenic amines profile of the analyzed wines. The first two principal components, PC1 and PC2, accounted for $59.22 \%$ of the total variance $(38.59 \%$ for PC1 and $20.63 \%$ for PC2), thus explaining a significant information in the dataset. The projection of the wines on the first two principal components showed a clear separation of the samples into two groups, according to the wine type (white vs. red) (Fig. 2a); red wines (R) were clearly separated from the white $(\mathrm{W})$ and rose wines. Red wines were mainly located in the positive part of PC1, while white wines were located in the negative part of PC1.

The principal components responsible for the differences in the BA composition of the wines produced were determined and presented in the scatter plot in Fig. 2b. The responsible components for the separation of red wines were CAD, PUT, HIST, TYR, PEA, and TRP, which were present in a higher concentration in red wines, prevailed in the positive part of the first principal component, while only SPD was characteristic

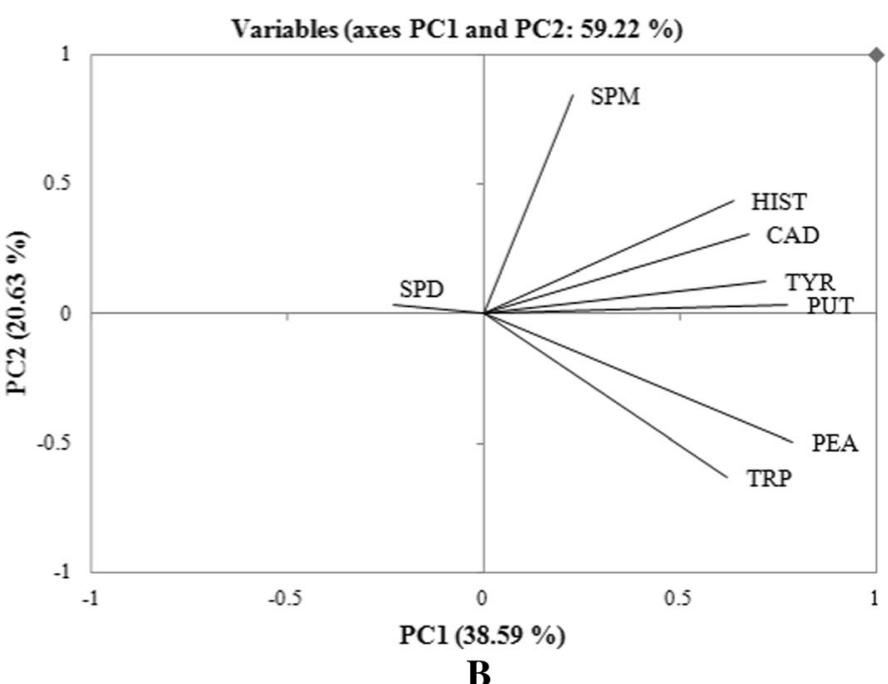

compounds. Labels of the wines correspond to the ones in Table 4. Abbreviations of compounds are explained in Table 1

for the white wines. So, the separation of the wines was observed according to the wine type (red vs. white; Fig. 3).

\section{Conclusion}

The proposed UPLC-TQ/MS method is suitable for fast, accurate, and simultaneous determination of the following biogenic amines: TRP, PUT, HIST, PEA, TYR, CAD, SPD, and SPM in red and white wines without previous derivatization. The developed method was validated showing satisfactory analytical performance without significant effect of the wine matrix on ionization efficiency (except for spermine). The method was then applied for analysis of real samples, Macedonian red and white wines, observing that red wines presented higher content of amines compared to the white wines. All wines contained biogenic amines in concentration levels lower than the maximal allowed. For the first time, biogenic amine content was determined in local varieties grown in Republic of Macedonia such as white wines Žilavka, Temjanika, and Smederevka and red wines Kratošija and Kadarka.

Acknowledgements Financial support provided by the Macedonian Ministry of Education and Science for the bilateral project between Republic of Macedonia and Montenegro titled "Biogenic amines and aroma in Vranec wines from Macedonia and Montenegro and effect of malolactic fermentation on their formation" is gratefully acknowledged.

\section{Compliance with Ethical Standards}

Funding Funding was provided by the Macedonian Ministry of Education and Science of the Republic of Macedonia. 
Conflict of Interest Krste Tašev declares that he has no conflict of interest. Violeta Ivanova-Petropulos declares that she has no conflict of interest. Marina Stefova declares that she has no conflict of interest.

Ethical Approval This article does not contain any studies with animals.

Informed Consent It was obtained from all individual participants included in the study.

\section{References}

Alcaide-Hidalgo JM, Moreno-Arribas MV, Martín-Álvarez PJ, Polo MC (2007) Influence of malolactic fermentation, postfermentative treatments and ageing with lees on nitrose compounds of red wines. Food Chem 103:572-581

Anli ER, Bayram M (2009) Biogenic amines in wines. Food Rev Int 25: 86-102

Arrieta MP, Prats-Moya MS (2012) Free amino acids and biogenic amines in Alicante Monastrell wines. Food Chem 135:1511-1519

Bauza T, Blaise A, Daumas F, Cabanis JC (1995) Determination of biogenic amines and their precursor amino acids in wines of the Vall ee du Rhone by high-performance liquid chromatography with precolumn derivatization and fluorimetric detection. J Chromatogr A 707:373-379

Daniel D, Dos Santos VB, Vidal DT, Lago CL (2015) Determination of biogenic amines in beer and wine by capillary electrophoresistandem mass spectrometry. J Chromatogr A 1416:121-128

EFSA Panel on Biological Hazards (2011) Scientific opinion on risk based control of biogenic amine formation in fermented foods. EFSA J 9(10):1-93

Fernandes JO, Ferreira MA (2000) Combined ion-pair extraction and gas chromatography-mass spectrometry for the simultaneous determination of diamines, polyamines and aromatic amines in port wine and grape juice. J Chromatogr A 886:183-195

García-Marino M, Trigueros Á, Escribano-Bailón T (2010) Influence of oenological practices on the formation of biogenic amines in quality red wines. J Food Comp Anal 23:455-462

García-Villar N, Hernández-Cassou S, Saurina J (2009) Determination of biogenic amines in wines by pre-column derivatization and highperformance liquid chromatography coupled to mass spectrometry. $\mathrm{J}$ Chromatogr A 1216:6387-6393

Goñi DT, Azpilicueta CA (2001) Influence of yeast strain on biogenic amines content in wines: relationship with the utilization of amino acids during fermentation. Am J Enol Viticul 52:185-190

Guo YY, Yang YP, Peng Q, Han Y (2015) Biogenic amines in wine: a review. Int J Food Sci Tech 50:1523-1532

Hernández-Orte P, Peña-Gallego A, Ibarz MJ, Cacho J, Ferreira V (2006) Determination of the biogenic amines in musts and wines before and after malolactic fermentation using 6-aminoquinolyl-Nhydroxysuccinimidyl carbamate as the derivatizing agent. J Chromatogr A 1129:160-164

Hernández-Orte P, Lapeña AC, Peña-Gallego A, Astrain J, Baron C, Pardo I, Polo L, Ferrer S, Cacho J, Ferreira V (2008) Biogenic amine determination in wine fermented in oak barrels. Factors affecting formation. Food Res Int 41:697-706

Herrero M, García-Cañas V, Simo C, Cifuentes A (2014) Recent advances in the application of capillary electromigration methods for food analysis and foodomics. Electrophoresis 35:147-169

Hlabangana L, Hernandez-Cassou S, Saurina J (2006) Determination of biogenic amines in wines by ion-pair liquid chromatography and post-column derivatization with 1,2-naphthoquinone-4-sulphonate. J Chromatogr A 1130:130-136
Jastrzębska A, Piasta A, Kowalska S, Krzemiński M, Szłyk E (2016) A new derivatization reagent for determination of biogenic amines in wines. J Food Comp Anal 48:111-119

Kelly MT, Blaise A, Larroque M (2010) Rapid automated high performance liquid chromatography method for simultaneous determination of amino acids and biogenic amines in wine, fruit and honey. $\mathrm{J}$ Chromatogr A 1217:7385-7392

Landete JM, Ferrer S, Pardo I (2007) Biogenic amine production by lactic acid bacteria, acetic bacteria and yeast isolated from wine. Food Control 103:1475-1486

Lange J, Wittmann C (2002) Enzyme sensor array for the determination of biogenic amines in food samples. Anal Bioanal Chem 372:276 283

Littlewood JT, Gibbs C, Glover V, Sandler M, Davies PTG, Rose F (1988) Red wine as a cause of migraine. Lancet 1(8585):558-559

Lonvaud-Funel A (2001) Biogenic amines in wines: role of lactic acid bacteria. FEMS Microbiol Lett 199:9-13

Loukou Z, Zotou A (2003) Determination of biogenic amines as dansyl derivatives in alcoholic beverages by high-performance liquid chromatography with fluorimetric detection and characterization of the dansylated amines by liquid chromatography-atmospheric pressure chemical ionization mass spectrometry. J Chromatogr A 996:103113

Maintz L, Novak N (2007) Histamine and histamine intolerance. Am J Clin Nutr 85:1185-1196

Manetta AC, Di Giuseppe L, Tofalo R, Martuscelli M, Schirone M, Giammarco M, Suzzi G (2016) Evaluation of biogenic amines in wine: determination by an improved HPLC-PDA method. Food Control 62:351-356

Marcobal A, de la Rivas B, Muñoz R (2006) Methods for the detection of bacteria producing biogenic amines on foods: a survey. J Verbrauch Lebensm 1:187-196

Marques AP, Leitão MC, San Romão MV (2008) Biogenic amines in wines: influence of oenological factors. Food Chem 107:853-860

Martín-Álvarez PJ, Marcobal A, Polo C, Moreno-Arribas MV (2006) Influence of technological practices on biogenic amine contents in red wine. Eur Food Res Technol 222:420-424

Martuscelli M, Arfelli G, Manetta AC, Suzzi G (2013) Biogenic amines content as a measure of the quality of wines of Abruzzo (Italy). Food Chem 140:590-597

Millies KD, Zimlich D (1988) Histamingehalte von Weinen und Schaumweinen. Weinwirtsch Tech 1:21-24

Moreno-Arribas VM, Polo MC (2005) Winemaking biochemistry and microbiology: current knowledge and future trends. Crit Rev Food Sci Nutr 45:265-286

Onal A (2007) A review: current analytical methods for the determination of biogenic amines in foods. Food Chem 103:1475-1486

Ozdestan O, Üren A (2009) A method for benzoyl chloride derivatization of biogenic amines for high performance liquid chromatography. Talanta 78:1321-1326

Pérez-Serradilla JA, Luque de Castro MD (2008) Role of lees in wine production: a review. Food Chem 111:447-456

Preti R, Vinci G (2016) Biogenic amine content in red wines from different protected designations of origin of southern Italy: chemometric characterization and classification. Food Anal Method 9:2280-2287

Preti R, Vieri S, Vinci G (2016) Biogenic amine profiles and antioxidant properties of Italian red wines from different price categories. J Food Comp Anal 46:7-14

Rios AL, Valcarel M (1998) Direct determination of biogenic amines in wine by integrating continuous flow clean-up and capillary electrophoresis with indirect UV detection. J Chromatogr A 803:249-260

Romero R, Gázquez D, Bagur MG, Sánchez-Vinas M (2000) Optimization of chromatographic parameters for the determination of biogenic amines in wines by reversed-phase high-performance liquid chromatography. J Chromatogr A 871:75-83 
Sagratini G, Fernandez-Franzon M, De Berardinis F, Font G, Vittori S, Manes J (2012) Simultaneous determination of eight underivatised biogenic amines in fish by solid phase extraction and liquid chromatography tandem mass spectrometry. Food Chem 132:537-543

Sentellas S, Nuñez Ó, Saurina J (2016) Recent advances in the determination of biogenic amines in food samples by (U)HPLC. J Agric Food Chem 64:7667-7678

Smit AY, du Toit WJ, du Toit M (2008) Biogenic amines in wine: understanding the headache. S Afr J Enol Vitic 29:109-127

Soufleros E, Barrios M, Bertrand A (1998) Correlation between the content of biogenic amines and other wine compounds. Am J Enol Vitic 49:266-278
Spano G, Russo P, Lonvaud-Funel A, Lucas P, Alexandre H, Grandvalet C, Coton E, Coton M, Barnavon L, Bach B, Rattray F, Bunte A, Magni C, Ladero V, Alvarez M, Fernández M, Lopez P, de Palencia PF, Corbi A, Trip H, Lolkema JS (2010) Biogenic amines in fermented foods. Eur J Clin Nutr 64:S95-S100

Tašev K, Ivanova-Petropulos V, Stefova M (2016) Optimization and validation of a derivatization method for analysis of biogenic amines in wines using RP-HPLC-DAD. Maced J Chem Chem En 35:19-28

Vidal-Carou MC, Lahoz-Portoles F, Bover-Cid S, Marine-Font A (2003) Ion-pair high-performance liquid chromatographic determination of biogenic amines and polyamines in wine and other alcoholic beverages. J Chromatogr A 98:235-241 